Original Research Paper

\title{
Application of the Wildlife Conservation 2010 (Act 716): The Malaysian Experience
}

\author{
Kamal Halili Hassan \\ Faculty of Law, Universiti Kebangsaan Malaysia, Bangi, 43600, Selangor, Malaysia
}

Article history

Received: $25-07-2014$

Revised: $18-12-2014$

Accepted: 19-12-2014

\begin{abstract}
This article examines offences committed by persons or entities under the Malaysian Wildlife Conservation Act 2010. The problem is that although there is already legislation being currently enforced yet offences on animals and wildlife is on the rise in Malaysia. Among the common offences are wildlife smuggling, sale of unlawfully hunted wildlife, hunting without permit, unlawful delivery of wildlife using courier services and keeping or using protected animals without authorization which is the more rampant of the offences. This paper discusses the rationale for the 2010 Act, licensing and permit requirements and the types of offences committed under the Act. The article also explores the charges levied against parties violating the Act and penalties imposed. The conclusion that can be made from this paper is that offences committed under the 2010 Act were quite rampant as showed in the tables.
\end{abstract}

Keywords: Wildlife Conservation, Malaysia, Animals, Welfare, PERHILITAN

\section{Introduction}

Concerns over the treatment and management of animals and wildlife has been on the rise globally (Duncan and Fraser, 1997), with both governments and Non-Governmental Organizations (NGOs) playing their roles in creating and enhancing this public awareness (Appleby, 1999; Whittaker et al., 2012). Governments in many parts of the world have enacted laws to ensure the protection and conservation of animals and wildlife while NGOs contribute to the effort by ensuring that the government stays focused and continue its enforcement of the law. The meaning of animal welfare has changed over time (Broom, 1991). Where previously it related to an individual's feelings that animals as god's creation should not be harmed (Duncan, 1996), it now has assumed greater dimensions to cover the enactment and enforcement of legislation by governments to provide for animal protection and conservation (Fraser, 1995). Most countries now have specific laws that protect animal welfare and it is already a global movement where the protection of animal welfare is taken seriously not only by governments and NGOs but also the public at large (Kiley-Worthington, 1989; Centner and Smeshko, 2011). The concept and measurement of animal welfare also differ and have evolved over time (Hewson, 2003). How do we measure and determine the criteria for animal welfare standards and norms? Legislation has already formulated the measurement where animal welfare is determined in terms of food, hygiene, health, sanctuary, confinement and other treatments (Fraser et al., 1997). For example, animal and wildlife in zoos are protected by specific regulations (Hassan, 2014; Hosey et al., 2009; Kleiman et al., 2010). Detailed provisions have been provided for in the relevant legislation for all aspects of animal welfare and special government agencies established to enforce the law. Thus animal welfare is not just a matter of science (Darcan et al., 2007; Krogh and Enevoldsen, 2012) to determine their wellbeing and lives but also an issue of social science especially when it concerns public awareness and legal enforcement (Duncan, 2002; Rezai et al., 2013). Whether animal 'welfare' can turn into an issue of 'right' is debatable (Rollin, 2006), but it is clear that there are laws to ensure compliance with legal provisions and penalties for those who flout them. Management of animals is crucial whether for exhibition purposes or during occurrences of crisis or accidents, for example in zoos (Groh, 2014).

Malaysia has also been active in protecting and conserving its animals and wildlife with the enactment of the overriding Wildlife Conservation Act (Yoga, 2012). Since it came into force on 28 December 2010, 
prosecutions for offences committed under the Act have been instituted against violations such as illegal possession of protected wildlife, smuggling, illegal hunting, encroachment and technical offences. The Act defines 'wildlife' as any species of wild animal or wild bird, whether totally protected or protected, vertebrate or invertebrate, live or dead, mature or immature and whether or not may be tamed or bred in captivity. Protected and totally protected wildlife are of different categories and both have been listed accordingly in the schedule of the Act. The Department of Wildlife and National Parks (PERHILITAN) is tasked with the enforcement of the Act.

\section{Materials and Methods}

The main material used in this research is the Wildlife Conservation Act 2010 (Act 716) which applies to Peninsular Malaysia and the Federal Territory of Labuan. It does not apply to any wildlife falling within List II of the Ninth Schedule of the Federal Constitution and the Fisheries Act 1985 (Act 317). The Act has 136 sections and 7 schedules. The ministry concerned has passed two regulations under the Act, i.e., the Wildlife Conservation (Compounding of Offences) Regulations 2011 and the Wildlife Conservation (Operations of Zoos) Regulations 2012 (Hassan, 2014; Yoga, 2012). A related legislation referred to in this study is the International Trade in Endangered Species 2008 (Act 686). The author also relies on two main documents, i.e., the PERHILITAN annual reports of 2011 and 2012 which contain much useful information on the work of the department and data on the enforcement of the Act.

The methodology adopted in this research is mainly qualitative with major reliance on references and analysis of the relevant legislation and other secondary sources. Primary data refers to legislation, regulations, parliamentary documents and court cases. Interview is also a method frequently used in legal research and considered as primary source of information, which the author used with officials of PERHILITAN. Secondary data refers to publications such as articles, journals, books, thesis and official departmental documents. Legal research can be categorized into analytical, comparative, historical and contextual approaches (Yaqin, 2007). In this study, the author has mainly used the contextual approach.

\section{Results}

The main aim of the 2010 Act is to protect and conserve wildlife. PERHILITAN controls and monitors wildlife through the requirement for licences and permit which persons and operators involved need to apply. Part 111 (sections 9-25) relates to matters concerning licencing. According to section 9, no person shall, (a) hunt or keep any protected wildlife; (b) take or keep any part or derivative of any protected wildlife; (c) collect birds' nests; (d) carry on the business of dealing; (e) carry on taxidermy business; and (f) import, export or reexport any protected wildlife or any part or derivative of any protected wildlife, unless that person holds a licence granted under the Act. A separate licence is required for each activity of dealing. Under section 10 , a permit is required for any party to operate a zoo, a commercial captive breeding enterprise, a circus or wildlife exhibition and to conduct research or study on any protected wildlife. For certain activities, a special permit is required especially for activities on any totally protected wildlife.

Table 1. Offences committed under the Wildlife Conservation Act 2010 (2011 and 2012, Peninsular Malaysia)

\begin{tabular}{lllllll}
\hline Year & Illegal possession & Smuggling & Illegal Hunting & Encroachment & Technical offences & Total \\
\hline 2011 & 217 & 34 & 2 & 1 & 210 & 475 \\
2012 & 143 & 45 & 4 & 1 & 161 & 354 \\
\hline
\end{tabular}

Source: PERHILITAN Annual Reports 2011 and 2012

Table 2. Offences under the 716 and 686 Acts, 2011 and 2012, Selangor

\begin{tabular}{|c|c|c|c|c|c|c|c|c|}
\hline No. & IP No. & Date & Species & Category & No & Section & Fine (MR) & Or Imprisonment (months) \\
\hline 1 & HQ 0009/12 & $13 / 3 / 2012$ & Lesser Green Leafbird & Totally protected & 8 & $68(1)(a)$ & 10,000 & 6 \\
\hline 2 & HQ 0009/12 & $13 / 3 / 2012$ & Stripe-throated bulbul & Totally protected & 10 & $68(1)(a)$ & 10,000 & 6 \\
\hline 3 & HQ 0009/12 & $13 / 3 / 2012$ & Asian Fairy Bluebird & Totally protected & 5 & $68(1)(a)$ & 10,000 & 6 \\
\hline 4 & HQ 0009/12 & $13 / 3 / 2012$ & White-Rumped Sharma & Protected & 6 & $60(1)(b)$ & 7,000 & 3 \\
\hline 5 & HQ 0009/12 & $13 / 3 / 2012$ & Blue \& Gold Macau & Protected & 1 & $60(1)(b)$ & 7,000 & 3 \\
\hline 6 & HQ 0009/12 & $13 / 3 / 2012$ & African Grey Parrot & Protected & 2 & $60(1)(b)$ & 7,000 & 3 \\
\hline 7 & HQ 0009/12 & $13 / 3 / 2012$ & Eastern Rosella & Protected & 2 & $60(1)(b)$ & 7,000 & 3 \\
\hline 8 & $003 / 11$ & $8 / 2 / 2011$ & American Alligator (Skin) & - & 50 & Act 686 & - & Court Action \\
\hline 9 & $003 / 11$ & $8 / 2 / 2011$ & Crocodile (Skin) & - & 44 & s. 10(b) of Act 686 & - & Court Action \\
\hline 10 & $006 / 11$ & $16 / 2 / 2011$ & Alexandrine Parakeet & - & 1 & s. 10 (b) of Act 686 & 10,000 & - \\
\hline 11 & 019/11 & $23 / 2 / 2011$ & License & - & - & $22,83,37$ & 1,000 & - \\
\hline 12 & $024 / 11$ & $24 / 2 / 2011$ & License & - & - & 22,37 & 1,100 & - \\
\hline
\end{tabular}

Source: PERHILITAN Annual Reports 2011 and 2012 
Table 3. Prosecutions under the 2010 Wildlife Conservation Act, (January-June, 2014)

\begin{tabular}{llr}
\hline No & Offence & No. of cases \\
\hline 1 & Smuggling of wild animals & 35 \\
2 & Sale of wildlife unlawfully hunted & 25 \\
3 & Hunting without permit & 8 \\
4 & Unlawful delivery of wildlife using courier service & 6 \\
5 & Keeping or using protected animals without permission & 479 \\
\hline
\end{tabular}

Source: Bernama 2014, www.bernama.com

Offences committed under the Act are provided under several sections with the notable ones being sections 60,61, 62 68, 10 and 12. Sections 60 and 68 are the more frequently ones invoked by the prosecution. The former is on offences related to (a) hunting or keeping any protected wildlife or (b) taking or keeping any part or derivative of any protected wildlife without a licence, which on conviction attracts a fine not exceeding RM50,000.00 or to imprisonment for a term not exceeding two years or both. Section 68 refers to the same illegal activities but is confined to totally protected wildlife and the penalty is higher, i.e., a fine not exceeding RM100,000.00 or imprisonment not exceeding three years or both.

\section{Discussion}

Table 1 shows the number of offences committed under the Act while Table 2 shows the various offences charged under the 716 and 686 Acts for the state of Selangor. According to Table 1 there was a decline in the total number of offences committed between 2011 and 2012 from 475 to 354 although smuggling and illegal hunting increased. However, these numbers are still considered high.

Table 2 shows a sample study of prosecutions carried out under the 716 and 686 Acts. The author only chose the state of Selangor as a sample as it has among the highest cases of violations of the Act for 2011-2012. Most charges were brought under sections 68 and 60 of the 716 Act and the majority of those convicted pleaded guilty and paid the fine. Illegally imported species vary but the most common is birds. Beautiful live birds attract much demand from local markets and this is the reason why such illegal activities have been rampant in Malaysia. Based on the author's interview with PERHILITAN officials on 30th May 2014, the department has been very active in instituting legal actions against offenders under the 2010 Act with prosecutions carried out by both the Headquarters and state authorities.

Recently, the Minister of Natural Resources and Environment (Bernama, 2014) reported that a total of 553 cases of violations under the Wildlife Conservation Act 2010 were detected between January and June of 2014 (Table 3) with the highest number of offence, at a staggering 479, involving the keeping or using of protected animals without permission. For 2014, the state of Johor recorded the most number of cases (91), followed by Selangor (860) and Kedah (76). The number of wildlife seized by PERHILITAN includes snake parts (362), live Murai Batu birds (344), African grey parrots (260) and deer parts (12). Cases of attempted smuggling of wild animals at various entry points included: Kuala Lumpur International Airport (25), Bayan Lepas International Airport, Penang (9) and Padang Besar, Perlis (1). So far 27 cases have been filed at the courts between January and June 2014 and 16 were disposed (fined). The heaviest penalty was imposed on a Vietnamese woman who was fined RM70,000.00 for smuggling monitor lizards. From the above figures, it can be seen that there has been a dramatic increase in violations under the Act in the first half of 2014.

\section{Conclusion}

From the above discussion, it is found that offences committed under the 2010 Act were quite rampant. The number of offences is considerably high considering the size of the country. This could be due to several factors such as the low level of awareness of the legal requirements under the Act, general apathy and poor consideration of animal welfare among the public and the high demand for wildlife. It is hoped that with rigorous enforcement of Acts No. 716 and 686, more offenders will be subject to legal action and eventually reduce the number of violations to ensure greater protection and conservation of wildlife and animals in the country. The limitation of this study is that it used several cases of offences as committed in some states only. Thus only sample of cases are chosen as representing the pattern of offences on animals for the whole country. The Federal Government monitors the enforcement of the laws through the Ministry of Environment and Natural Resources but the enforcement of the law is carried by officers of the state departments. Further research need to be carried out on this area of study especially on the issues of wildlife smuggling under the WTO legal regime and animal cruelty in Malaysia and Islamic teaching.

\section{Acknowledgement}

The author wishes to record his appreciation to the Sumitomo Foundation, Japan for awarding research grant 
(No. 138425) and also to Universiti Kebangsaan Malaysia and PERHILITAN for their assistance in this project.

\section{Ethics}

The author has obtained permission from the relevant authority (PERHILITAN MALAYSIA) in carring out this research vide letter reference number: JPHL\&TN(IP):80-4/2 Jld17(12) of 22 October 2013. Statistics are obtained from PERHILITAN annual report and BERN.

\section{References}

Appleby, M.C., 1999. What Should We Do About Animal Welfare? 1st Edn., Oxford: Blackwell Science, ISBN-10: 0632050667, pp: 204.

Broom, D.M., 1991. Animal welfare: Concepts and measurements. J. Anim. Sci., 69: 4167-4175.

Centner, T.J. and N. Smeshko, 2011. Compensating companion animal owners for veterinary malpractice through an alternative dispute resolution mechanism. J. Soc. Sci., 7: 597-604.

Darcan, N., F. Cedden and O. Guney, 2007. Spraying effects on goat welfare in hot and humid climate. Am. J. Anim. Vet. Sci., 2: 99-103. DOI: 10.3844/ajavsp.2007.99.103

Duncan, I.J.H. and D. Fraser, 1997. Understanding Animal Welfare. In: Animal Welfare, Appleby, M.A. and B.O. Hughes (Eds.), Wallingford, UK: CABI Publication, pp: 19-31.

Duncan, I.J.H., 1996. Animal welfare defined in terms of feelings. FAO, Guelph Univ. Ontario, Canada.

Duncan, I.J.H., 2002. Poultry welfare: Science or subjectivity? Brit. Poultry Sci., 43: 643-652. DOI: $10.1080 / 0007166021000025109$

Fraser, D., 1995. Science, values and animal welfare: Exploring the 'Inextricable Connection'. Anim. Welfare, 4: 103-117.

Fraser, D., D.M. Weary, E.A. Pajor and B.N. Milligan, 1997. A scientific conception of animal welfare that reflects ethical concerns. Anim. Welfare, 6: 187-205.
Groh, M., 2014. Strategic management in times of crisis. Am. J. Econ. Bus. Admin., 6: 49-57.

Hassan, K.H., 2014. Occupational and animals safety in zoos: A legal narrative. Am. J. Anim. Vet. Sci., 9: 1-5.

Hewson, C.J., 2003. What is animal welfare? Common definitions and their practical consequences. Can. Vet. J., 44: 496-499.

Hosey, G., V. Melfi and S. Pankhurst, 2013. Zoo Animals: Behaviour, Management and Welfare, Oxford University Press, ISBN-10: 0199693528, pp: 696.

Kiley-Worthington, M., 1989. Ecological, ethological and ethically sound environments for animals: Toward symbiosis. J. Agric. Ethics, 2: 323-247. DOI: $10.1007 /$ BF01826810

Kleiman, D.G., K.V. Thompson and C.K. Baer, 2010. Wild Mammals in Captivity: Principles and Techniques for Zoo Management, 1st Edn., University of Chicago Press, Chicago, ISBN-10: 0226440117, pp: 720.

Krogh, M.A. and C. Enevoldsen, 2012. Management of data for health performance measurement in the industrialized dairy herd. Am. J. Anim. Vet. Sci., 7: 159-174. DOI: 10.3844/ajavsp.2012.159.174

Rezai, G., P.K. Teng, Z. Mohamed and M.N. Shamsudin, 2013. Is it easy to go green? Consumer perception and green concept. Am. J. Applied Sci., 10: 793-800. DOI: 10.3844/ajassp.2013.793.800

Rollin, B.E., 2006. Animal Rights and Human Morality. 3rd Edn., Prometheus Books, New York, ISBN: 10-1591024218, pp: 400.

Whittaker, A.L., W.H.V. Wettere and P.E. Hughes, 2012. Space requirements to optimize welfare and performance in group housed pigs-a review. Am. J. Anim. Vet. Sci., 7: 48-54. DOI: 10.3844/ajavsp.2012.48.54

Yaqin, A., 2007. Legal Research and Writing. Kuala Lumpur: LexisNexis. pp: 276.

Yoga, S.S., 2012. New regulation seeks to improve zoo conditions. The Star Online. 